\title{
STUDI DESKRIPTIF TENTANG KESABARAN IBU BEKERJA DALAM MENGASUH ANAK HIPERAKTIF DI SDN PUTRACO-INDAH
}

\author{
Lisa W., Kintan M., Andhini F., Risha W. \\ Universitas Islam Bandung, Jl. Taman Sari no. 1 \\ e-mail:1_wido@yahoo.co.id
}

\begin{abstract}
Each parent was given a great responsibility, extraordinary privilege and grace as a role model that determines life, perhaps even growing someone who someday will become parents too. For working mothers, they are required to be able to divide their time between work and family time. In a phenomenon that we have encountered, working mother and have a hyperactive child often experience stress. This is caused by the condition of the mother when went home after office are facing some difficulties in controlling their child behavior. For that it takes the patience of a mother in particular who work in raising children are hyperactive so that later the child can maximize his or her potential.
\end{abstract}

Keywords: patience, working mom, hyperactive children.

\begin{abstract}
Abstrak
Setiap orang tua diberikan tanggung jawab yang besar, kesempatan yang luar biasa dan panutan yang baik yang menentukan kehidupan seseorang yang kelak akan menjadi orangtua juga. Untuk ibu bekerja, mereka dituntut untuk dapat membagi waktu antara bekerja dan bagi kehidupan keluarga. Pada fenomena yang peneliti temui, ibu yang bekerja dan memiliki anak yang hiperaktif seringkali mengalami stress. Hal ini disebabkan oleh kondisi ibu ketika pulang kantor yang dihadapkan dengan perilaku anak yang sulit dikendalikan. Untuk keadaan tersebut diperlukan kesabaran seorang ibu, khususnya yang membesarkan anak hiperaktif sehingga kelak nanti anak tersebut dapat memaksimalkan potensi yang mereka miliki.
\end{abstract}

Kata kunci: kesabaran, ibu bekerja, anak hiperaktif.

\section{PENDAHULUAN}

Ibu memiliki peran yang sangat penting didalam proses tumbuh kembang awal anaknya. Perilaku anak ketika masih belum duduk dibangku sekolah merupakan tanggung jawab orang tua sepenuhnya dalam mendidik dan membimbing anak.

Bagi ibu yang bekerja, mereka dituntut untuk dapat membagi waktu antara pekerjaan dan waktu untuk keluarga. Aktifitas ibu dalam bekerja untuk mencari nafkah akan sangat berpengaruh pada perkembangan anak. Meluangkan waktu bersama dengan anak menjadi suatu hal yang sangat penting karena anak merupakan titipan Allah SWT kepada orang tua untuk dijaga, dibimbing serta dididik agar kelak dapat mengaplikasikan ilmu pengetahuan yang akan berguna di dunia dan akan menyelamatkannya di akhirat. Anak memang terkadang adalah ujian bagi orang tuanya. Jika ibu mampu bersabar dalam mendidik mereka tentu akan ada pahala dari Allah yang lebih, dan kelak ibu akan menuai buah dari kesabaran yang manis. Setelah anaknya dewasa, mereka telah terbiasa dan terdidik dengan kebaikan yang ibu ajarkan dan mereka manusia yang taat pada Rabb-nya

Setiap ibu akan mengharapkan memiliki anak yang normal. Baik itu normal secara psikis maupun fisik. Menurut teori psikologi perkembangan, anak yang normal secara psikis pada usia-usia tertentu anak tersebut memang akan akan melewati masa dimana anak akan sulit dinasehati. Tetapi jika orang tua anak tersebut mampu me- 
mahami dan selalu membimbing anaknya untuk dapat mengetahui hal yang benar dan yang salah, anak tersebut akan lebih mudah untuk dapat mematuhi aturan yang diberikan orang tua.

Namun ternyata tidak semua orang tua memiliki anak dengan kondisi fisik atau psikis yang normal. Terdapat pula orang tua yang memiliki anak dengan kondisi psikis yang tidak normal khususnya pada kasus yang kami teliti adalah anak dengan gangguan hiperaktif dimana anak tidak mampu memusatkan perhatian dan impulsif. Bukan merupakan hal yang mudah untuk dapat mengasuh anak yang hiperaktif, terlebih lagi khususnya pada ibu yang juga bekerja. Dari hasil wawancara yang dilakukan, semua ibu menyatakan bahwa mereka yakin kelak anaknya akan mampu lebih terarah jika ibu terus menerus mendidik dengan penuh kesabaran. Ibu tidak akan pantang menyerah untuk selalu mengasuh anaknya yang hiperaktif meskipun tidak dipungkiri terkadang merasa sangat lelah dan stress.

Pada fenomena yang kami temui, ibu yang bekerja dan memiliki anak yang hiperaktif seringkali mengalami stress. Hal ini disebabkan oleh kondisi ibu ketika pulang kantor yang dihadapkan dengan perilaku anak yang sulit dikendalikan. Dengan kondisi seperti itu, ibu yang merasa lelah dengan tuntutan pekerjaan kantor merasa pekerjaannya tidak berhenti hingga anaknya tertidur. Hasil dari wawancara dengan beberapa subjek ketika ibu menghadapi keadaan stress, ibu mengatasi keadaan tersebut dengan sejenak menghela nafas panjang dan ber-istighfar dengan tetap sabar mengurus anaknya yang cenderung selalu ingin bersama dengan ibunya meskipun disana ada ayah atau pengasuh anak. Ibu tidak pernah memperlakukan anaknya dengan kasar, baik secara verbal maupun non-verbal, melainkan hanya beristighfar dan membujuk anaknya untuk dapat mau mendengarkan.

Untuk itulah dibutuhkan kesabaran seorang ibu khususnya yang bekerja dalam mengasuh anaknya yang hiperaktif agar kelak anak dapat memaksimalkan potensi di- rinya. Pengertian sabar yang sesuai dengan fenomena yang kami temui adalah pengertian sabar menurut kitab al-Aeni jld 2, hal.46, yang artinya:

"Sabar itu adalah menahan marah dengan sekuat tenaga dan kemampuan".

Hal ini tergambar ketika ibu merasa sudah lelah dengan tuntutan pekerjaan di kantor dan ketika pulang ke rumah masih dihadapkan dengan perilaku anaknya yang sulit dikendalikan. Perasaan kesal dan marah pada anak, ditahan dengan sekuat tenaga dan kemampuan ibu demi membuat anaknya senang dan sedikit demi sedikit mau mendengarkan hingga anaknya bisa tenang dan tertidur.

Selain itu dilihat dari pembagian sabar menurut para ulama, sabar terbagi menjadi 3 yaitu sabar dalam melaksanakan ibadah, sabar dalam meninggalkan maksiat dan sabar ketika mendapat musibah (ujian) hidup. Seorang ibu yang bekerja dan memiliki anak yang hiperaktif tergolong kepada sabar dalam melaksanakan ibadah dan sabar ketika mendapat musibah (ujian) hidup. Hal ini karena mengurus anak adalah suatu ibadah bagi seorang ibu. Mencintai anaknya dengan sepenuh hati serta tanpa kenal lelah dan penuh keyakinan bahwa anaknya dapat menjadi anak yang kelak mampu mengoptimalkan potensinya. Sabar ketika mendapat musibah (ujian) hidup karena anak terkadang menjadi suatu ujian bagi orang tua khususnya pada kasus ini adalah bagi ibu. Selalu mengingat Allah SWT dengan beristigfar dan tidak putus asa selalu berusaha adalah salah satu hal yang mencerminkan sabar ketika mendapat ujian dari Allah SWT melalui anak yang hiperaktif.

Berdasarkan latar belakang di atas peneliti tertarik untuk meneliti "Studi Deskriptif Tentang Kesabaran Ibu Bekerja Dalam Mengasuh Anak Hiperaktif di SDN Putraco-Indah"

Tujuan penelitian ini adalah untuk mendapatkan gambaran mengenai kesabaran ibu yang bekerja dalam mengasuh anak 
hyperaktif di SDN Putraco-Indah. Adapun beberapa manfaat yang akan diperoleh dari hasil penelitin ini, diantaranya adalah sebagai berikut:

a. Secara Teoritis

Penelitian ini diharapkan dapat memberikan tambahan pengetahuan terkait dengan konsep teori kesabaran serta memperkuat konsistensi konsep dari variabel tersebut yang dikaitkan dengan integrasi antara ilmu psikologi dan agama Islam.

b. Secara Praktis

Hasil dari penelitian ini dapat dijadikan sebagai model bagi para Ibu yang bekerja dan memiliki anak yang hyperaktif, melalui gambaran profil ketekunan, ketabahan serta keteguhannya.

\section{SABAR}

Kata Sabar berasal dari bahasa Arab "Shabara - Shabura - Shabaran Shabaaratan" yang berarti menanggung atau menahan sesuatu. (Kamus AlMunjid, Penerbit: Al-Maktabah AsSyaqiyyah, hlm. 414 dalam Parihat Kamil, Kumpulan Materi Kapita Selekta, 2013).

Rangkaian huruf Shad, $B a$, dan $R a$ maknanya berkisar pada tiga hal, yaitu: "Menahan", "Ketinggian sesuatu", dan "Sejenis batu". Dari kata "Menahan", lahir makna "Konsisten; bertahan" karena yang bertahan menahan pandangannya pada satu sikap. Seseorang yang menahan gejolak hatinya dinamai sabar. Dari makna kedua lahir kata "Shubr", yang berarti puncak sesuatu. Sedangkan makna ketiga muncul kata "As-Shubrah", yakni batu yang kukuh lagi kasar atau "potongan besi"(Ahmad Yadi Yasin, Dahsyatnya Sabar, 2010).

Berdasarkan beberapa pengertian diatas, maka dapat disimpulkan bahwa sabar adalah mampu menahan diri atau mengendalikan diri dari segala keinginan, menerima ujian dengan tawakal, tenang serta tidak tergesa-gesa, dan melaksanakan perkuliahan mencapai tujuan untuk mengaharap ridha Allah.

\section{Aspek-Aspek Sabar}

Sabar dapat diartikan sebagai kemampuan individu untuk mengatur, mengendalikan, mengarahkan, dan mengatasi berbagai kebutuhan/permasalahan atau kesulitan yang dihadapi, secara komprehensif dan integratif.

Sabar ini dibagi menjadi tiga aspek, yaitu teguh pada pendirian atau prinsip, tabah, dan tekun.

Teguh Pada Pendirian atau Prinsip

Pengertian teguh menurut Kamus Besar Bahasa Indonesia, yaitu:

a. Kuat dalam menyelesaikan apa yang telah direncanakan

b. Berpegang teguh pada aturan dan tujuan tetap tidak berubah atau sesuai dengan yang telah direncanakan

Teguh memiliki aspek-aspek yaitu:

Konsekuen: bagaimana seseorang menyelesaikan sesuatu sesuai dengan apa yang telah direncanakan.

a. Keyakinan tentang apa yang sebaiknya dilakukan

b. Keberanian untuk mengambil resiko: mau menerima tantangan dalam pengerjaan sesuatu dengan segala kemungkinan yang baik ataupun buruk

Konsisten: bagaimana seseorang bertingkah laku secara tetap, selaras, dan sesuai dengan apa yang telah diyakininya dalam mencapai target.

Disiplin :

a. Taat terhadap aturan: menunjukkan bagaimana seseorang mampu dan mau taat terhadap aturan yang berlaku

b. Tertib dalam melaksanakan aturan: menunjukkan bagaimana seseorang menjalankan aturan yang berlaku secara terus menerus dan sistematis hingga mencapai target.

Tabah

Tabah adalah menggambarkan bagaimana kemampuan seseorang untuk tetap pada tujuan dan kuat menghadapi berbagai tantangan dan cobaan. 
Tabah berdasarkan dibagi menjadi beberapa sub aspek.

Daya juang adalah kekuatan dalam mem-perebutkan atau melaksanakan seluruh ke-giatannya memperoleh sesuatu atau dalam mencapai goal.

Toleransi terhadap stres: kemampuan menghadapi / mengatasi masalah yang dapat menimbulkan stress dalam pencapaian target.

Mampu belajar dari kegagalan: mampu melihat suatu hal yang gagal sebagai peluang untuk selalu memperbaiki hasil kerja menjadi lebih baik.

Bersedia menerima umpan balik untuk memperbaiki diri dan atau perilakunya : mau menerima masukan dari orang lain dan menjadikan masukan tersebut sebagai hal yang positif agar hasil yang dicapai menjadi lebih baik.

\section{Tekun}

Tekun melaksanakan pekerjaan atau tugas terus menerus hingga tujuan bisa tercapai. Tekun dibagi menjadi beberapa sub aspek, yaitu:

Antisipatif: tanggap terhadap sesuatu yang sedang/akan terjadi dan memilki rencana cadangan apabila menghadapi kesulitan dalam pencapaian target / tujuan.

Terencana: memiliki rencana-rencana dalam pencapaian tujuan dan merealisasikan rencana-rencana tersebut.

Terarah: mengarahkan energi pada pencapaian tujuan dalam proses pembelajaran.

\section{METODE PENELITIAN}

Penelitian ini menggunakan metode deskriptif yang dimaksudkan untuk mengumpulkan informasi mengenai status suatu gejala yang ada yakni gejala pada saat penelitian dilakukan. Penelitian deskriptif tidak ditujukan untuk menguji hipotesis tetapi hanya menggambarkan apa adanya tentang satu variabel, gejala atau keadaan (Arikunto, 2007:234). Penelitian deskriptif bertujuan untuk menggambarkan secara jelas, cermat, dan teliti tentang gejala- gejala yang akan diteliti. Adapun variabel yang diteliti adalah kesabaran yaitu kemampuan individu untuk mengatur, mengendalikan, mengarahkan, dan mengatasi berbagai kebutuhan/permasalahan atau kesulitan yang dihadapi, secara komprehensif dan integratif

Metode pengumpulan data yang digunakan berupa kuesioner dan interview sebagai alat pengumpul data yang pokok. Populasi penelitian ini adalah 23 ibu yang bekerja dan memiliki anak hiperaktif di SDN Putraco Indah serta beragama Islam.Teknik pengolahan data menggunakan teknik perhitungan prosentase.

\section{HASIL DAN PEMBAHASAN}

Dari pengolahan data diperoleh, bahwa dari populasi penelitian 18 orang $(78,3 \%)$ memiliki taraf kesabaran yang tinggi dan 5 orang $(21,7 \%)$ memiliki taraf kesabaran rendah. Hal ini dapat disimpulkan bahwa dengan kondisi tekanan anak hyperaktif, sebagian besar ibu yang bekerja masih mampu menunjukkan sikap kesabaran. Terlihat dari kesediaan ibu untuk meluangkan waktu dalam mengasuh anak hyperaktif. Ibu berani mengambil keputusan untuk bekerja meskipun memiliki anak hyperaktif. Memiliki optimisme akan dapat mengoptimalkan potensi anaknya yang hyperaktif. Selain itu ibu mampu mengontrol emosi ketika anak melakukan hal yang impulsive serta tetap qonaah dalam mengasuh anak hyperaktif. Ibu juga memperlakukan anaknya yang hyperaktif untuk dapat mengimbangi anak yang normal. Ibu mampu menjalankan tanggung jawab sesuai peran (ibu yang memiliki anak hyperaktif dan ibu yang bekerja) meskipun ibu merasakan tekanan emosional. Ibu melakukan segala cara agar dapat mengatasi tingkah laku anak yang impulsive. Memiliki kesiapsiagaan ketika anak melakukan hal impulsive. Ibu memiliki rencana lain ketika kesulitan mengasuh anak yang hyperaktif dan memiliki pengetahuan dalam mengasuh anak hiperaktif. Meski demikian masih terdapat 
$21,7 \%$ ibu-ibu yang belum mampu menunjukkan sikap diri untuk dapat mengendalikan situasi-situasi yang menekan yang dihadapinya.

Bila mengacu pada hasil perhitungan dari setiap aspeknya, diperoleh hasil sebagai berikut:

Tabel 1. Prosentase Aspek Kesabaran

\begin{tabular}{cccc}
\hline No. & Aspek & Rendah & Tinggi \\
\hline 1. & Teguh & $17,4 \%$ & $82,6 \%$ \\
2. & Tabah & $\mathbf{3 0 , 4 \%}$ & $69,6 \%$ \\
3. & Tekun & $21,7 \%$ & $78,3 \%$ \\
\hline
\end{tabular}

Dari tabel tersebut bahwa diantara ke 3 aspek yang membangun kesabaran, maka aspek teguh dan tekun adalah aspek-aspek yang memiliki katagori tinggi dengan prosentasi sangat besar. Artinya tingginya prosentase taraf kesabaran pada katagori tinggi disumbang oleh tingginya prosentase yang juga tinggi pada ke dua aspek tersebut. Sementara bila melihat aspek yang katagori rendahnya paling tinggi terdapat pada aspek tabah. Aspek tabah adalah aspek yang terkait dengan indikator daya juang, kemampuan toleransi terhadap stress, bersedia menerima umpan balik dan mampu belajar dari kegagalan. Pada indikator tersebut tampak masih terdapat responden yang berada pada taraf rendah. Kondisi ini dapat dipahami mengingat para responden dengan perannya sebagai ibu sekaligus juga pekerja sudah dihadapkan pada situasi yang memberi peluang adanya konflik. Situasi tersebut diperburuk dengan tuntutan perannya saat harus menerima dan menghadapi perilaku-perilaku ekstrim yang ditampilkan oleh anaknya yang tergolong hyperaktif. Situasi atau kondisi internal yang berasal dari diri pribadi responden dapat menjadi sumber yang memberikan kontribusi bagaimana kekuatan toleransi stress itu bekerja pada diri seseorang saat menghadapi tekanan-tekanan dari luar. Kepribadian yang dimiliki, diantaranya merupakan salah satu faktor internal yang dapat dikaitkan dengan kemampuan individu dalam mengelola emosi

\section{SIMPULAN DAN SARAN}

Ibu yang bekerja dan memiliki anak hiperaktif memiliki kesabaran yang tinggi. Hal itu terlihat dalam setiap aspek kesabaran yang diukur yaitu teguh, tabah, tekun. Berdasarkan aspek yang membangun kesabaran, maka aspek teguh dan tekun lebih memiliki nilai katagori tinggi yang lebih kuat dibanding aspek tabah.

\section{Saran}

1. Peningkatan pada indikator kemampuan daya juang, toleransi stress dapat diberikan dengan menggunakan teknik intervensi tertentu agar lebih mampu membangun kemampuan kesabaran lebih optimal.

2. Diperlukannya sosialisasi yang diadakan oleh pihak sekolah secara rutin untuk membagi informasi mengenai bagaimana mengatasi dan mengasuh anak hiperaktif ditinjau dari sisi psikologi dan sisi spiritual.

3. Bagi peneliti selanjutnya, perlu dilakukannya penelitian lebih lanjut dengan mengkorelasikan kesabaran dengan variabel lainnya.

\section{DAFTAR PUSTAKA}

Al Quran dan Terjemahan (Revisi Terbaru)

Departemen Agama RI.2000.

Semarang: CV. Asy-Syifa'

Balai Pustaka. (2005). Kamus Besar Bahasa Indonesia. Jakarta: Balai Pustaka.

Yusuf, Umar.(2010). Diktat Kuliah Psikologi Islam V. Bandung.

Amru Syaikh. 2003. Sabar dan Santun

Karakter Mukmin Sejati. Jakarta:

Pustaka Al-Kautsar

Noor, H. (2009). Psikometri. Aplikasi Dalam Penyusunan Instrumen Pengukuran Perilaku. Bandung: Fakultas Psikologi Unisba. 
Studi Deskriptif tentang Kesabaran Ibu Bekerja dalam Mengasuh Anak Hiperaktif di SDN Putraco-Indah (Lisa W., Kintan M., Andhini F., Risha W.)

Rachmad Mulyono. 2003. Sabar Dalam Al Quran. Bandung: Universitas Islam Bandung

Sobarna Ayi. 2010. Sabar Dalam Al Quran. Bandung: Universitas Islam Bandung

Mengenal Anak Hiperaktif http://id.novartis.com19.30/ $\quad 14$ Novermber 2014
Penyebab, ciri-ciri dan cara mengatasi anak hiperaktif http://ideguru.wordpress.com $18.10 /$ 10 November 2014

Syafrie, dkk. 2005. Statistik Deskriptif untuk Psikologi. Tidak diterbitkan. Fakultas Psikologi Unisba. 